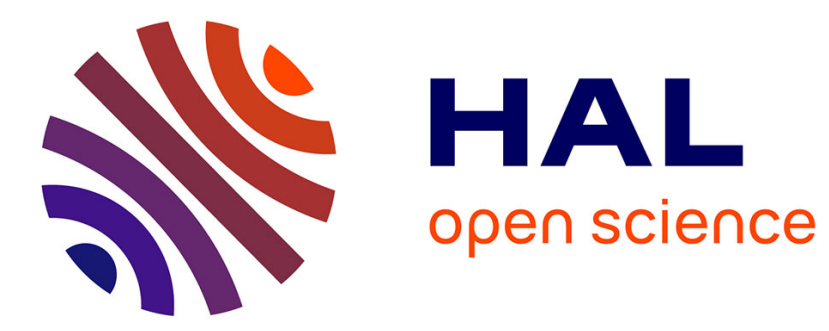

\title{
Demonstration of the Short-circuit Ruggedness of a 10 kV Silicon Carbide Bipolar Junction Transistor
}

\author{
Besar Asllani, Hervé Morel, Pascal Bevilacqua, Dominique Planson
}

\section{To cite this version:}

Besar Asllani, Hervé Morel, Pascal Bevilacqua, Dominique Planson. Demonstration of the Shortcircuit Ruggedness of a $10 \mathrm{kV}$ Silicon Carbide Bipolar Junction Transistor. EPE'20 ECCE Europe, Sep 2020, Lyon, France. 10.23919/EPE20ECCEEurope43536.2020.9215769 hal-02945919

\section{HAL Id: hal-02945919 https://hal.science/hal-02945919}

Submitted on 22 Sep 2020

HAL is a multi-disciplinary open access archive for the deposit and dissemination of scientific research documents, whether they are published or not. The documents may come from teaching and research institutions in France or abroad, or from public or private research centers.
L'archive ouverte pluridisciplinaire HAL, est destinée au dépôt et à la diffusion de documents scientifiques de niveau recherche, publiés ou non, émanant des établissements d'enseignement et de recherche français ou étrangers, des laboratoires publics ou privés. 


\title{
Demonstration of the Short-circuit Ruggedness of a $10 \mathrm{kV}$ Silicon Carbide Bipolar Junction Transistor
}

\author{
Besar Asllani ${ }^{1}$, Hervé Morel ${ }^{2}$, Pascal Bevilacqua ${ }^{2}$ and Dominique Planson ${ }^{2}$ \\ ${ }^{1}$ SuperGrid Institute \\ 23 rue Cyprian CS 50289 \\ 69628 Villeurbanne Cedex, France \\ Tel.: +33 / (7) -61.69.58.63. \\ E-Mail: besar.asllani@supergrid-institute.com \\ URL: http://www.supergrid-institute.com
}

${ }^{2}$ Univ Lyon, INSA Lyon, Ecole Centrale de Lyon, Université Claude Bernard Lyon 1, CNRS,
Ampère, F-69621 Villeurbanne, France

\section{Acknowledgements}

The authors wish to acknowledge CALY Technologies for their help with the design and fabrication. Acknowledgments are addressed to DeepConcept also for their help with packaging.

\section{Keywords}

«Power Semiconductor Device», «Silicon Carbide (SiC)», «Bipolar Junction Transistor», «MOSFET», «Robustness», «Reliability».

\begin{abstract}
Static, switching and short-circuit characterization of a $10 \mathrm{kV}$-class Silicon Carbide (SiC) Bipolar Junction Transistor (BJT) is reported. The $2.4 \mathrm{~mm}^{2} \mathrm{SiC}$ BJT show good static and switching behavior. The current gain is low compared to literature, but several issues have been identified and can be improved. For the first time, the Short-circuit ruggedness of a $10 \mathrm{kV} \mathrm{SiC-BJT}$ is reported. These tests show outstanding performance with at least $16 \mu$ s withstand time. Several samples have been brought to failure and revealed an outstanding $52.1 \mathrm{~J} / \mathrm{cm}^{2}$ of short-circuit critical energy at 32\% of breakdown voltage. The failure seems to happen on the top face metallization since the devices failed in blocked mode and the base-emitter terminals shorted. The SiC BJT handles without failing at least 3 times the critical Short-circuit energy of the commercial SiC MOSFETs. In addition, switching performance is much better than that of Si-IGBTs.
\end{abstract}

\section{Introduction}

SiC power devices are now hitting mass production for automotive applications [1]-[6]. These devices cover the $650 \mathrm{~V}-1700 \mathrm{~V}$ range. Higher-voltage devices were announced by the main manufacturers, but may take time to be brought to the market because of the high demand for automotive applications. As such, commercial devices for Medium Voltage and High-Voltage Direct Current (MVDC and HVDC) applications are not available yet. For these applications, high voltage (>10 kV) switches and diodes would be ideal. In addition, for such a high-voltage device, the unipolar conduction mode leads to higher conduction losses than the bipolar conduction mode [7]. For these reasons, at SuperGrid Institute the choice for bipolar devices was made and the specifications were: $10 \mathrm{kV}-50 \mathrm{~A} \mathrm{SiC}$ Bipolar Junction Transistors (BJT) and PiN diodes. This initiative yielded 3 production runs for PiN diodes and 1 run for BJTs. The fabricated devices were tested in static, dynamic and short-circuit conditions. Their state-of-the-art performance is reported in [8], [9]. This paper reports the superior 
short-circuit ruggedness of the $10 \mathrm{kV} \mathrm{SiC} \mathrm{BJT}$ and provides potential improvement ideas in order to yield an even better device with lower static and dynamic losses.

\section{Static Characteristics}

The structure of the BJT is an interdigitated device with a cell pitch between $25 \mu \mathrm{m}$ and $35 \mu \mathrm{m}$. Several geometrical variations were made on the emitter and base width in order to find the optimal design. The tested devices had a size of $2.6 \times 2.6 \mathrm{~mm}^{2}$ for an active area of $2.4 \mathrm{~mm}^{2}$. They were packaged in a custom.packaging for testing purposes only. The structure of the elementary cell pitch, the schematic packaging and the finished device are shown in Fig. 1 from left to right.
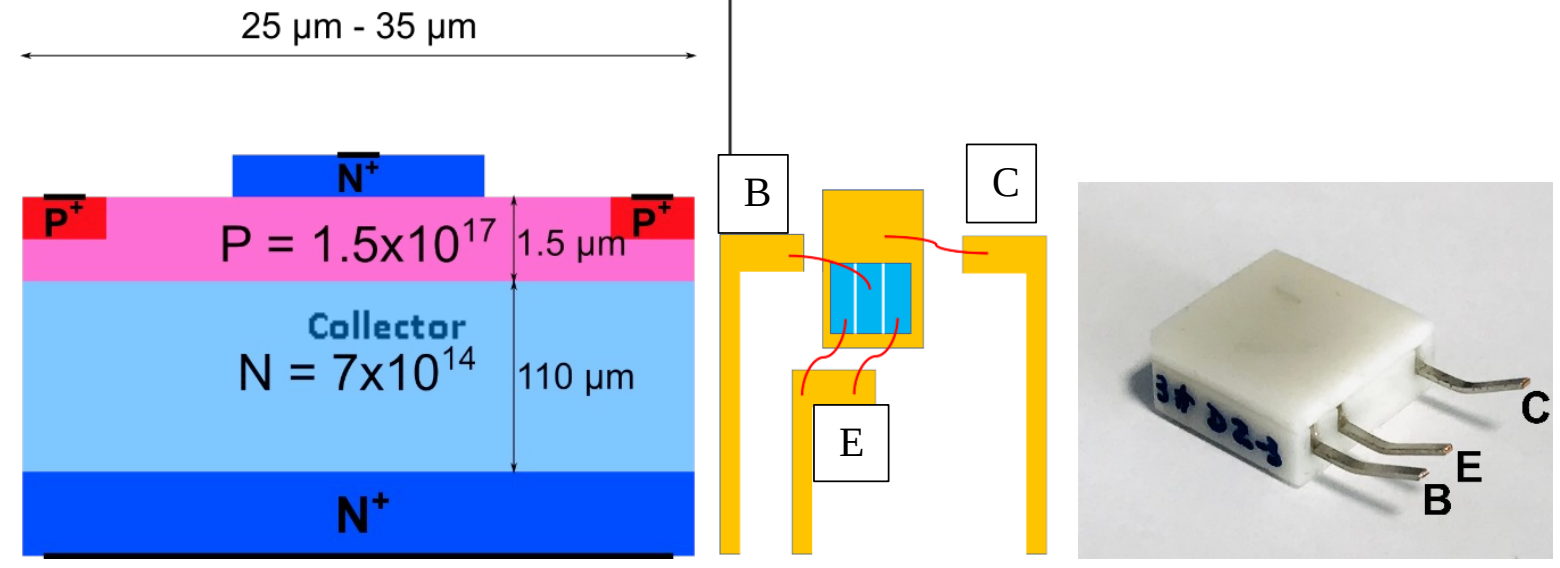

Fig. 1: The elementary cell pitch, the internal connection schematic and the finished packaged device from left to right.

For the breakdown voltage measurements, a FUG 12,5kV SMU in series with a Keithley 6485 Picoamperemeter was employed, while the device were placed in a vacuum chamber to prevent flashovers. As shown in Fig. 2, the breakdown voltage is half of the targeted one due to a fabrication defect. The peripheral protection implantation dose was higher than expected. This problem has been corrected for the third run of the PiN diodes that withstand more than $12 \mathrm{kV}$ [8]. The same improvement can be made on the BJT and the same results are expected.

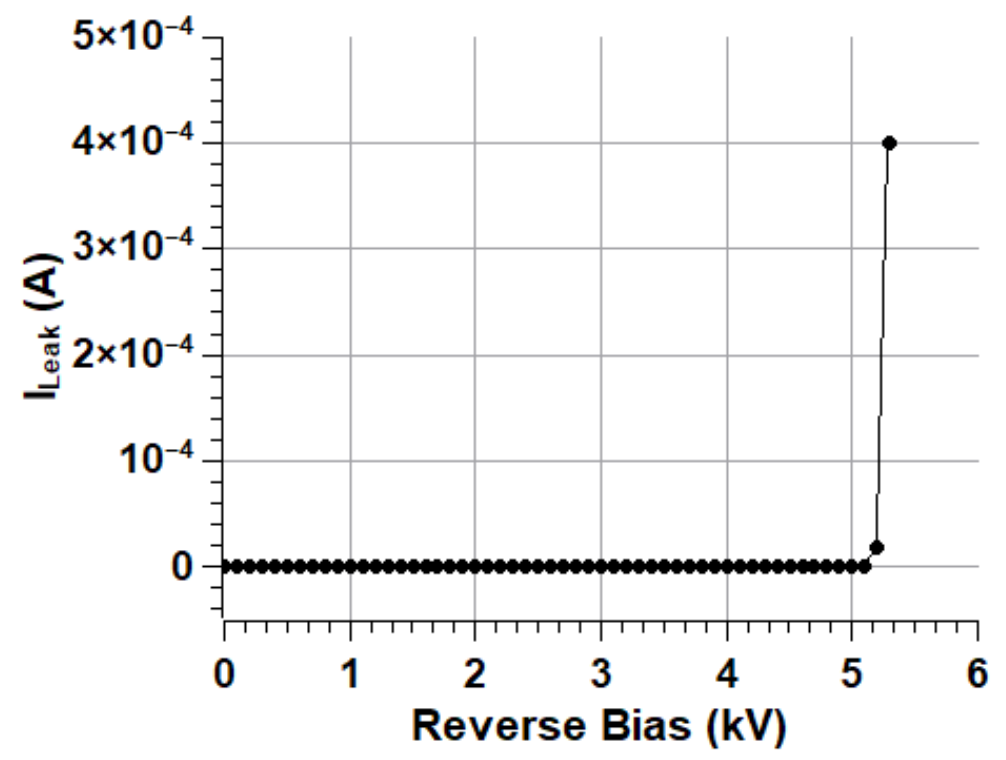


Fig. 2: The measured breakdown voltage of the $10 \mathrm{kV}$-class SiC BJT.

The static forward characterization of the devices have been carried out by means of a Keysight B1506. Due to voltage limitations (60 V max) of the Ultra High Current module of the device analyzer, it was impossible to measure the characteristics of the device beyond this limit. A custom test bench was used to enable higher base current and higher collector emitter bias. The output characteristics carried out on the B1506 are reported in Fig. 3 whereas in Fig. 4 they are compared to the results obtained on the custom test bench. The BJT responds well to the base current and a $4.5 \mathrm{~A}$ $\left(187 \mathrm{~A} / \mathrm{cm}^{2}\right)$ collector current can be injected at $60 \mathrm{~V}$ of collector emitter voltage and a base current of $1 \mathrm{~A}$. At $100 \mathrm{~A} / \mathrm{cm}^{2}$ the specific on-state resistance is about $198 \mathrm{~m} \Omega \cdot \mathrm{cm}^{2}$. But at a base current of $2 \mathrm{~A}$ and a collector current density of $200 \mathrm{~A} / \mathrm{cm}^{2}$ the on-state resistance drops to $120 \mathrm{~m} \Omega \cdot \mathrm{cm}^{2}$ which shows a resistivity modulation, classical in a bipolar device. For an epitaxy able to withstand $13 \mathrm{kV}$ [8], this value is slightly better than the unipolar limit and shows that resistivity modulation can be achieved on these devices.

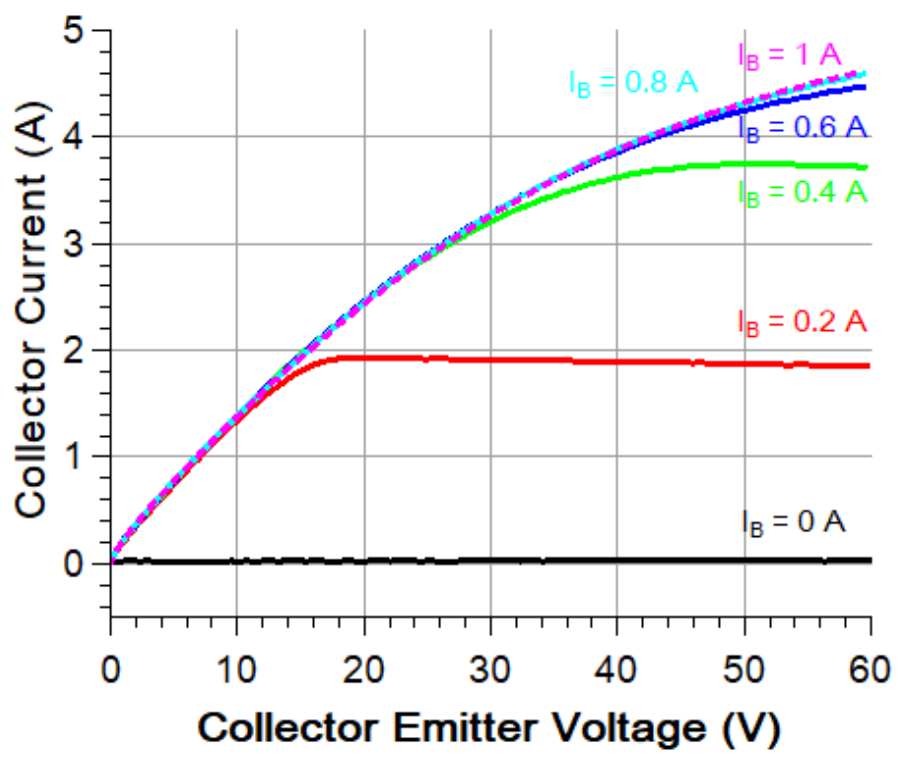

Fig. 3: The output characteristics of the $10 \mathrm{kV}$-class SiC BJT obtained with a B1506.

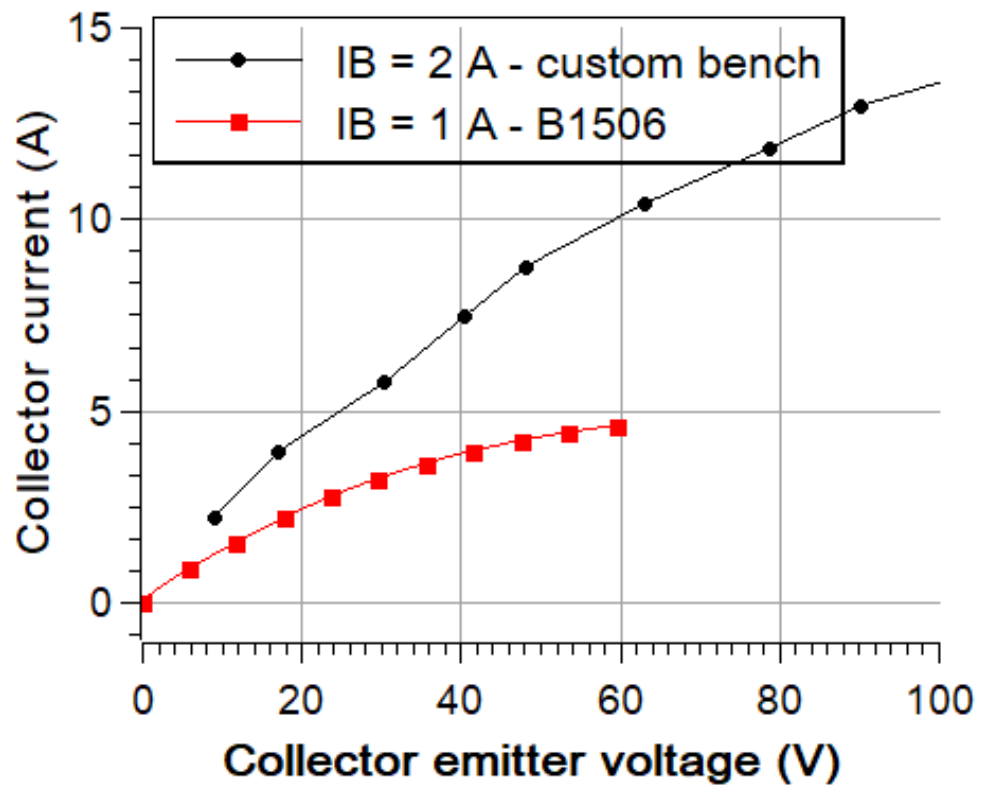

Fig. 4: The output characteristics of the $10 \mathrm{kV}$-class SiC BJT carried out on a B1506 (red squares) as compared to the results obtained on the custom test bench (black circles). 
The current gain has been measured both by means of a B1506 power device analyzer and with the custom test bench. The results obtained with the B1506 are reported in Fig. 5. The measurements have been carried out at room temperature and at $150{ }^{\circ} \mathrm{C}$. The best performing devices show a $\beta=9.5$ at room temperature. One other issue is related to base current and collector emitter voltage limitations of the device analyzer, which are respectively $1 \mathrm{~A}$ and $60 \mathrm{~V}$. As a matter of fact, the size of the device under test is too small and the base access resistance is too high, which leads to a high on-state resistance. B1506 device analyzers are conceived to characterize devices with higher current levels and lower on-state resistance.

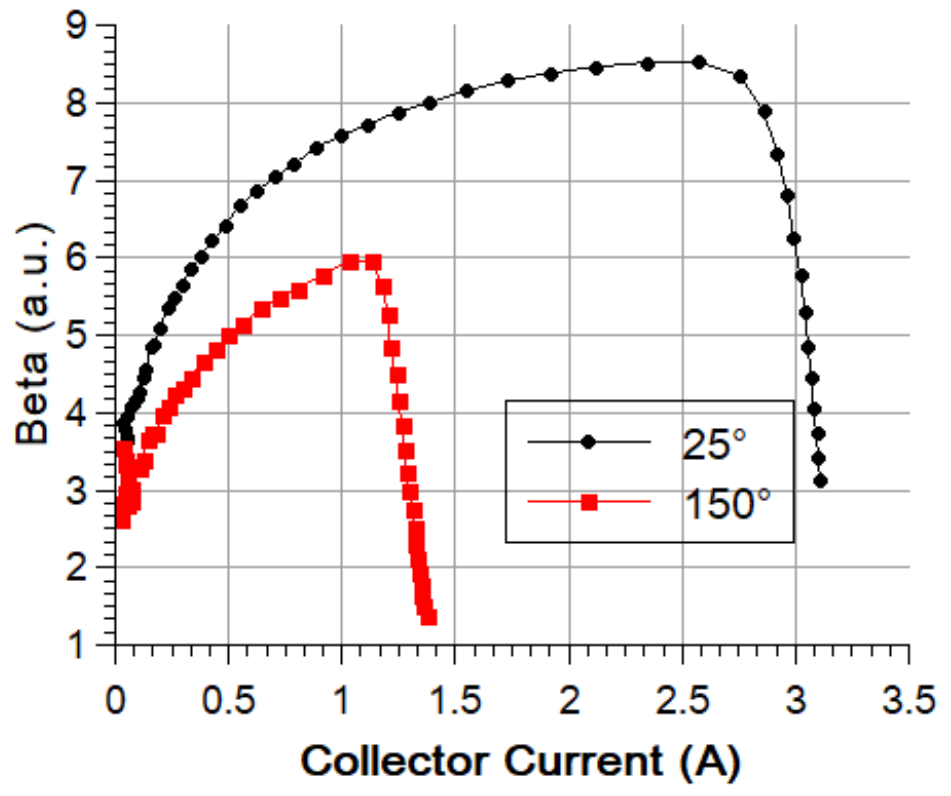

Fig. 5: Current gain of the BJT as a function of the current collector for $25^{\circ} \mathrm{C}$ (black dots) and $150^{\circ} \mathrm{C}$ (red squares) measured with a B1506.

With the custom test bench used for switching characterizations, we were able to observe current amplification values at a higher voltage. A maximum beta of 21 at a collector current of 20.5 A (854 $\mathrm{A} / \mathrm{cm}^{2}$ ) and a collector emitter voltage of $150 \mathrm{~V}$ was measured. 


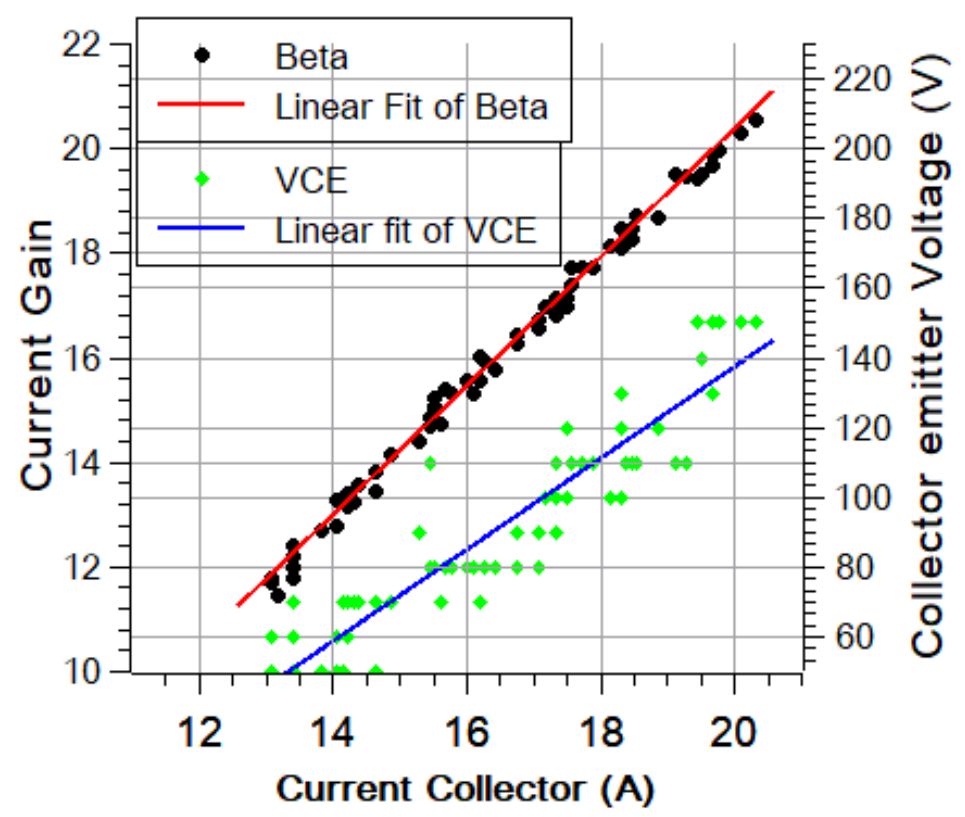

Fig. 6: Current gain and collector emitter voltage as function of the collector current at a base current of $1 \mathrm{~A}$.

The measurements were carried out on a short pulse configuration $(<10 \mu \mathrm{s})$ in order to mitigate selfheating effects which could alter the results. These measurements yield a beta of 21 for an on-state resistance of $175 \mathrm{~m} \Omega \cdot \mathrm{cm}^{2}$ at $854 \mathrm{~A} / \mathrm{cm}^{2}$. The current gain value can be considered to be low as compared to literature [10]-[16]. The reasons for this are both technological. First one is related to the thickness of the base layer which is chosen to be thick to avoid its punch. By an improvement of the depth of the base contact etching the thickness of the base layer can be greatly reduced. The second is related to the base current surface recombination due to interface traps present at the interface between the base and the passivation oxide [15], [17]-[20]. To reach a high current gain a small base width is needed, but that yields to a high base access resistance. To improve this, a higher interdigitation must be employed. Several techniques can be employed to improve the second parameter and can drastically lower both the on-state resistance and the power losses in the driver by increasing the current gain of the device. The identified improvements both in terms of breakdown voltage and current gain give hope for a better device with a bigger active area in a near future.

\section{Switching Characteristics}

The devices switching performances have been tested on a custom test bench. A $1.4 \mathrm{mH}$ air core inductor in parallel with two $1.7 \mathrm{kV}$ JBS diodes in series were mounted on the high side while the SiC BJT was mounted on the low side. The driver used for the BJT base emitter junction biasing is the formerly commercial GA15DDJT22-FR4 SJT driver from GeneSiC. This driver is capable of providing a typical current of $7 \mathrm{~A}$ at the turn on and $2 \mathrm{~A}$ continuous. The schematic of the test bench is shown in Fig. 7. The switching waveforms produced with this setup are shown in Fig. 8 and confirm the outstanding performance of the $10 \mathrm{kV}$-class SiC BJT. Turn-on happens in less than 90 ns and turnoff in less than $100 \mathrm{~ns}$. Both the $d V / d t$ and $d i / d t$ measured during the switching are very high compared to silicon devices. The turn-on (at $417 \mathrm{~A} / \mathrm{cm}^{2}$ ) and turn-off (at $854 \mathrm{~A} / \mathrm{cm}^{2}$ ) energies are as low as 133 $\mathrm{mJ} / \mathrm{cm}^{2}$ and $717 \mathrm{~mJ} / \mathrm{cm}^{2}$ respectively. The driver losses are not included in the calculation as the actual driver is not optimized for this device, but for the sake of clarity they are shown in Fig. 9. Driver losses can be significant since the current amplification is relatively low compared to literature. 




Fig. 7: Double pulse test setup used to characterize the BJT.





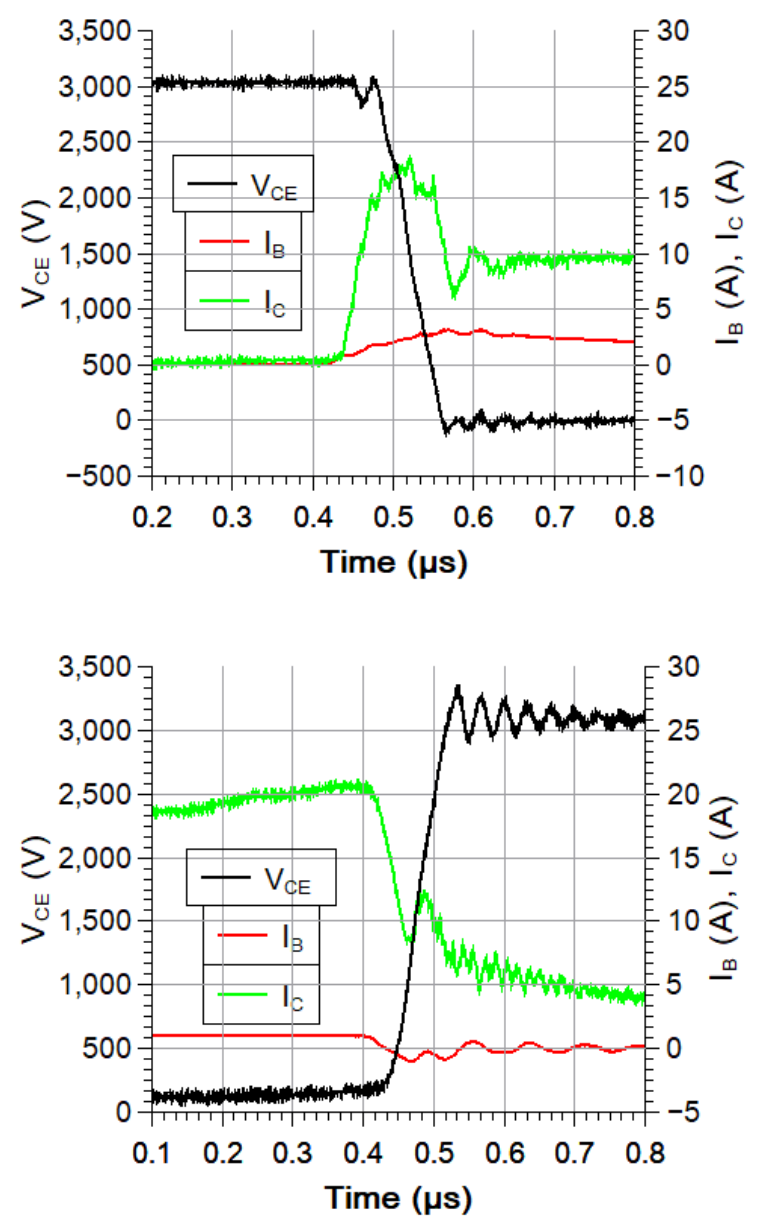

Fig. 8: Switching waveforms of $10 \mathrm{kV} \mathrm{SiC} \mathrm{BJT.} \mathrm{Full} \mathrm{wave} \mathrm{(up),} \mathrm{turn-on} \mathrm{(left),} \mathrm{turn-off} \mathrm{(right)}$

Due to the problem with the peripheral protection, the BJT switching performance assessment was limited to a $3 \mathrm{kV}$ bus voltage.


Fig. 9: Base emitter voltage and base current (left) and the resulting drivers power losses (right).

The driver losses are shown in Fig. 9 (right). One can observe that most of the losses are due to the constant base current bias. An optimized BJT with higher current gain would lower these losses and make them negligible compared to the switching losses of the device. 


\section{Short-Circuit Tests}

The main interest of this paper is the short-circuit robustness of the $10 \mathrm{kV}$-class SiC BJT. Theoretically SiC BJTs should outperform both planar and trench SiC MOSFETs in terms of shortcircuit withstand time and critical energy. This is expected since the temperature of the MOSFET's channel increases rapidly when submitted to short-circuit conditions and since the channel is close to the gate oxide a significant portion of the heat is transferred to the latter [21]-[23]. This endangers the MOSFET especially when very high voltage is applied. On the other hand, the SiC BJT does not have a gate oxide. This means that even if the temperature in the BJT rises above the MOSFET's critical temperature it will not be damaged as much since the conduction happens in the volume of the SiC. To prove this point, for the first time in the knowledge of the authors, short-circuit tests were carried out on a $10 \mathrm{kV} \mathrm{SiC} \mathrm{BJT.} \mathrm{The} \mathrm{resulting} \mathrm{waveforms} \mathrm{are} \mathrm{reported} \mathrm{in} \mathrm{Fig.} \mathrm{10.} \mathrm{One} \mathrm{can} \mathrm{see} \mathrm{that} \mathrm{the} \mathrm{applied}$ voltage is $3250 \mathrm{~V}$ and the short-circuit duration has been varied from $3 \mu$ s to $16 \mu$ s without showing any signs of degradation or failure. The BJT was able to block no matter the duration of the shortcircuit.

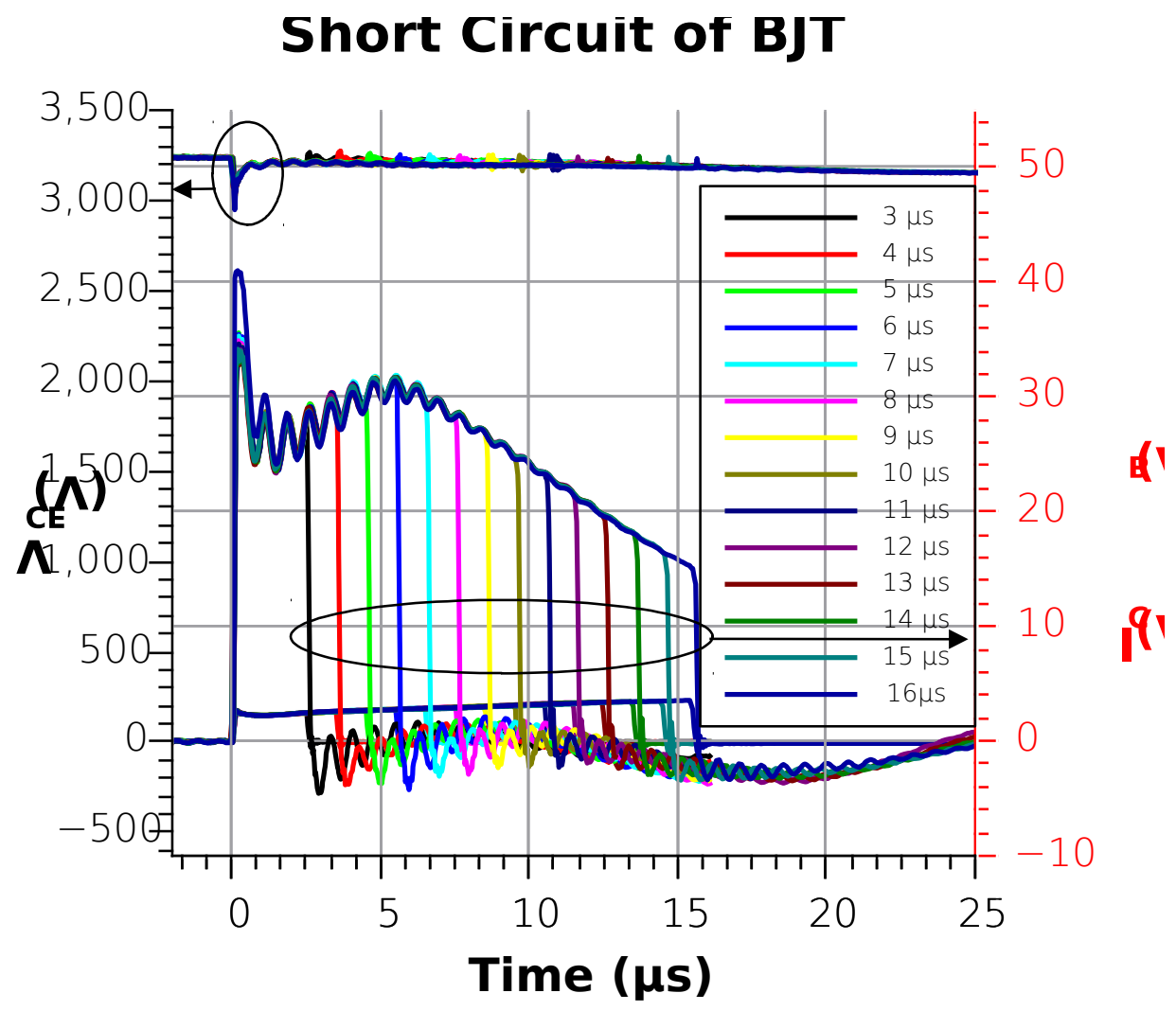

Fig. 10: Short-circuit ruggedness of the $10 \mathrm{kV} \mathrm{SiC} \mathrm{BJT.} \mathrm{No} \mathrm{degradation} \mathrm{or} \mathrm{failure} \mathrm{was} \mathrm{observed} \mathrm{even}$ at $16 \mu$ duration

The energy that was dissipated in the device equals $1.25 \mathrm{~J}$ which corresponds to $52.1 \mathrm{~J} / \mathrm{cm}^{2}$ if we consider only the active area. This amount of energy density is at least 3 times higher $\left(16,4 \mathrm{~J} / \mathrm{cm}^{2}\right)$ than the best performing (short-circuit wise) $1200 \mathrm{~V}$ discrete SiC MOSFET of the market [24]. 


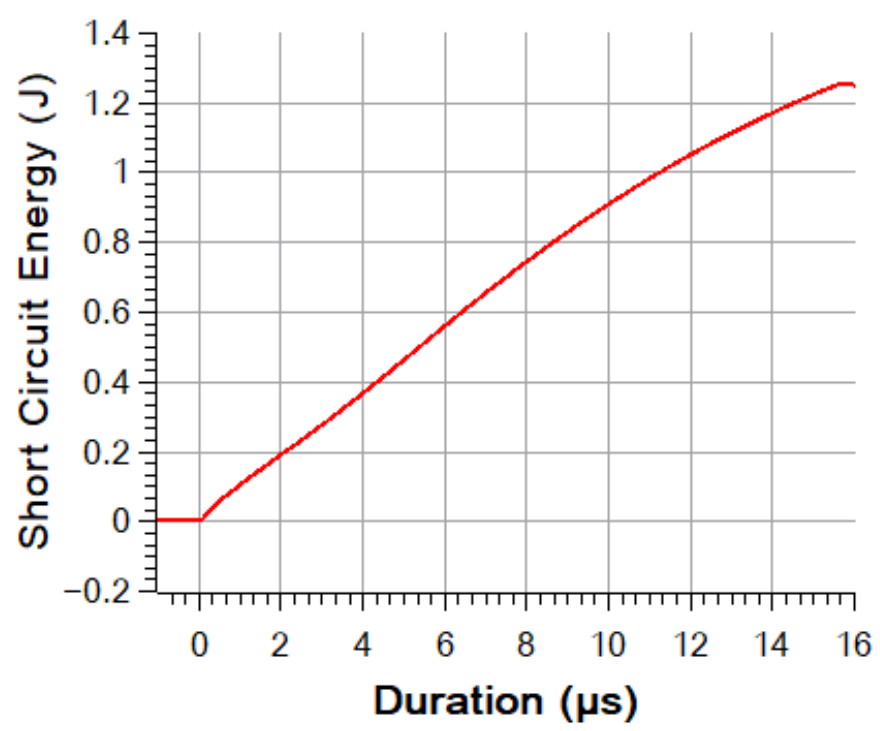

Fig. 11: Energy dissipated in the $10 \mathrm{kV}$ SiC BJT during a 16 us short-circuit event.

Several devices were brought to failure after repetitive (1 s apart) short-circuit events. The results presented in Fig. 12 were obtained while increasing the short-circuit duration. The first pulse which lasts $15 \mu$ s is apparently creating some damage. The second attempt reveals the effect of the damage since the collector current exhibits some delay compared to the base current pulse. Once triggered the devices seems to withstand the short-circuit. The collector current rises to the nominal value as compared to the previous test. On the third attempt even though the base current is exactly the same as previously, the device does not switch on but behaves as a current limiter. After measurement, the base and emitter contacts show a short-circuit behavior which witnesses the fusion and shorting of the top layer metallization. This can be considered as a "safe" failure mode since the device would limit the current and slowly shut down instead of going into thermal runaway [25]-[27]. This behavior has been observed on commercially available $1200 \mathrm{~V} \mathrm{SiC} \mathrm{MOSFETs} \mathrm{under} \mathrm{very} \mathrm{particular} \mathrm{short-circuit}$ bias [24] and is a feature that could be exploited in future application. One advantage of the power BJT is the absence of gate oxide and all the related reliability issues. If no explicit test of the baseplane dislocation aging was carried out, no observation which would imply this phenomenon was made, despite the numerous static characterizations and high-current commutation measurement on the tested BJTs.

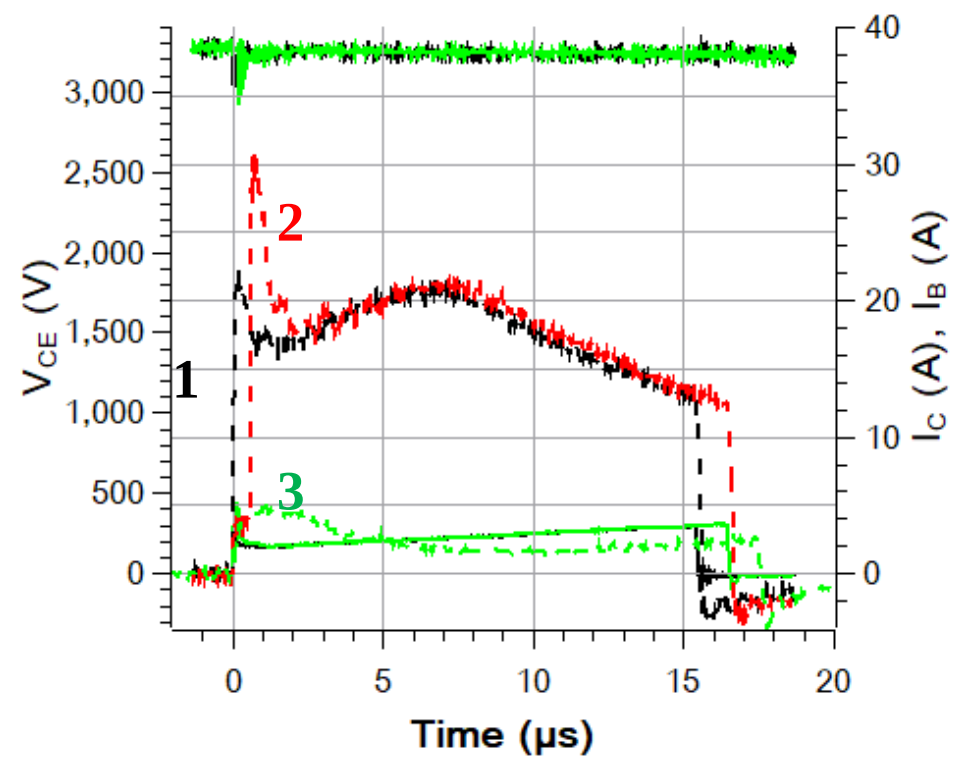


Fig. 12: Failure of the $10 \mathrm{kV}$-class SiC BJT after 2 repetitive short-circuit events $1 \mathrm{~s}$ apart. The dotted curves stand for the collector current. On the third try the device behaves as a current limiting device.

\section{Conclusion}

The $10 \mathrm{kV}$-class SiC BJT static, switching and short-circuit performance were assessed. The device has a current gain of at least 21 at a very high current density $\left(854 \mathrm{~A} / \mathrm{cm}^{2}\right)$. The gain has to be improved for the sake of the driver simplicity and power losses. The device shows outstanding switching times and an exceptional short-circuit ruggedness. This confirms that the SiC BJTs are far more robust than SiC MOSFETs in terms of short-circuit and may find their place in applications where this property is required. The critical short-circuit energy density of the BJT is $52.1 \mathrm{~J} / \mathrm{cm}^{2}$. "Safe" short-circuit failure mode was identified where the device shuts down due to a short between base and emitter electrodes. High temperature $\left(>150^{\circ} \mathrm{C}\right)$ applications can be enabled due to the absence of gate oxide and its related robustness issues.

\section{References}

[1] “Applications | Automotive.” [Online]. Available: https://www.genesicsemi.com/applications/. [Accessed: 27-Aug-2019].

[2] "E-Series Automotive MOSFETs and Diodes | Wolfspeed,” 2018. [Online]. Available: https://www.wolfspeed.com/e-series. [Accessed: 27-Aug-2019].

[3] A. Marshaly, "The potential of Silicon carbide (SiC) for automotive applications," 2017. [Online]. Available: https://www.eenewseurope.com/design-center/potential-silicon-carbide-sic-automotiveapplications. [Accessed: 27-Aug-2019].

[4] “ON Semiconductor Announces SiC Diodes for Demanding Automotive Applications,” 2018. [Online]. Available: https://www.onsemi.com/PowerSolutions/newsItem.do?article=4112. [Accessed: 27-Aug2019].

[5] “Automotive SiC Diodes - STMicroelectronics.” [Online]. Available: https://www.stmicroelectronics.com.cn/en/automotive-analog-and-power/automotive-sic-diodes.html. [Accessed: 27-Aug-2019].

[6] "SiC for automotive applications.” [Online]. Available: https://www.infineon.com/cms/en/product/promopages/sicatv/. [Accessed: 27-Aug-2019].

[7] D. Johannesson, M. Nawaz, K. Jacobs, S. Norrga, and H. P. Nee, "Potential of ultra-high voltage silicon carbide semiconductor devices,” in WiPDA 2016 - 4th IEEE Workshop on Wide Bandgap Power Devices and Applications, 2016, pp. 253-258.

[8] Asllani, Morel, Phung, and Planson, " 10 kV Silicon Carbide PiN Diodes—From Design to Packaged Component Characterization,” Energies, vol. 12, no. 23, p. 4566, Nov. 2019.

[9] B. Asllani, P. Bevilacqua, H. Morel, D. Planson, L.V. Phung, B. Choucoutou, T. Lagier and M. MermetGuyennet, "Static and Switching Characteristics of $10 \mathrm{kV}$-class Silicon Carbide Bipolar Junction Transistors and Darlingtons,” pp. 1-10, ICSCRM’19 - Kyoto - Japon - 29 Septembre - 04 octobre 2019.

[10] A. Salemi, H. Elahipanah, K. Jacobs, C.-M. Zetterling, and M. Ostling, "15 kV-Class Implantation-Free 4H-SiC BJTs With Record High Current Gain,” IEEE Electron Device Lett., vol. 39, no. 1, pp. 63-66, Jan. 2018.

[11] H. Elahipanah, A. Salemi, C. M. Zetterling, and M. Östling, "5.8-kV implantation-free 4H-SiC BJT with multiple-shallow-trench junction termination extension,” IEEE Electron Device Lett., vol. 36, no. 2, pp. 168-170, Feb. 2015.

[12] H. Miyake, T. Okuda, H. Niwa, T. Kimoto, and J. Suda, "21-kV SiC BJTs with space-modulated junction termination extension,” IEEE Electron Device Lett., vol. 33, no. 11, pp. 1598-1600, 2012.

[13] S. Sundaresan, S. Jeliazkov, B. Grummel, and R. Singh, "10 kV SiC BJTs - Static, switching and reliability characteristics," in 2013 25th International Symposium on Power Semiconductor Devices \& IC's (ISPSD), 2013, pp. 303-306.

[14] S. Asada, J. Suda, and T. Kimoto, "Demonstration of Conductivity Modulation in SiC Bipolar Junction Transistors With Reduced Base Spreading Resistance,” IEEE Trans. Electron Devices, vol. PP, pp. 1-5, 
2019.

[15] S. Asada, J. Suda, and T. Kimoto, "Determination of Surface Recombination Velocity From CurrentVoltage Characteristics in SiC p-n Diodes,” IEEE Trans. Electron Devices, vol. 65, no. 11, pp. 47864791, Nov. 2018.

[16] Q. C. J. Zhang, R. Callanan, A. K. Agarwal, A. A. Burk, M. J. O'Loughlin, J. W. Palmour, C. Scozzie, "10 kV, 10 A Bipolar Junction Transistors and Darlington Transistors on 4H-SiC,” Mater. Sci. Forum, vol. 645-648, pp. 1025-1028, Apr. 2010.

[17] S. Asada, J. Suda, and T. Kimoto, "Effects of Parasitic Region in SiC Bipolar Junction Transistors on Forced Current Gain,” Mater. Sci. Forum, vol. 924, pp. 629-632, Jun. 2018.

[18] R. Ghandi et al., "Surface-Passivation Effects on the Performance of 4H-SiC BJTs," IEEE Trans. Electron Devices, vol. 58, no. 1, pp. 259-265, Jan. 2011.

[19] M. Domeij, H.-S. Lee, E. Danielsson, C.-M. Zetterling, M. Ostling, and A. Schoner, "Geometrical effects in high current gain 1100-V 4H-SiC BJTs,” IEEE Electron Device Lett., vol. 26, no. 10, pp. 743745, Oct. 2005.

[20] R. Ghandi, H. S. Lee, M. Domeij, B. Buono, C. M. Zetterling, and M. Östling, "Fabrication of 2700-V $12-\Omega \cdot \mathrm{cm} 2$ non ion-implanted 4H-SiC BJTs with common-emitter current gain of 50," IEEE Electron Device Lett., vol. 29, no. 10, pp. 1135-1137, Oct. 2008.

[21] G. Romano, L. Maresca, M. Riccio, V. d'Alessandro, G. Breglio, A. Irace, A. Fayyaz, A. Castellazzi, "Short-circuit Failure Mechanism of SiC Power MOSFETs," in 2015 IEEE 27th International Symposium on Power Semiconductor Devices \& IC's (ISPSD), 2015, pp. 345-348.

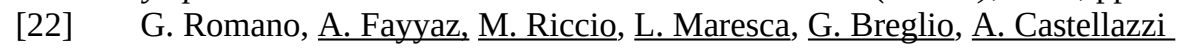

, “A comprehensive study of short-circuit ruggedness of silicon carbide power MOSFETs," IEEE J. Emerg. Sel. Top. Power Electron., vol. 4, no. 3, pp. 978-987, 2016.

[23] A. Fayyaz, "Performance and robustness characterisation of SiC power MOSFETs.” Thesis Nottingham University.

[24] F. Boige, "Caractérisation et modélisation électrothermique compacte étendue du MOSFET SiC en régime extrême de fonctionnement incluant ses modes de défaillance : Application à la conception d'une protection intégrée au plus proche du circuit de commande,” Sep. 2019, Thesis INPT Toulouse.

[25] F. Boige and F. Richardeau, "Gate leakage-current analysis and modelling of planar and trench power SiC MOSFET devices in extreme short-circuit operation,” Microelectron. Reliab., vol. 76-77, pp. 532538, Sep. 2017.

[26] F. Boige, F. Richardeau, D. Trémouilles, S. Lefebvre, and G. Guibaud, "Investigation on damaged planar-oxide of $1200 \mathrm{~V}$ SiC power MOSFETs in non-destructive short-circuit operation," Microelectron. Reliab., vol. 76-77, pp. 500-506, Sep. 2017.

[27] C. Chen, D. Labrousse, S. Lefebvre, M. Petit, C. Buttay, and H. Morel, "Study of short-circuit robustness of SiC MOSFETs, analysis of the failure modes and comparison with BJTs," Microelectron. Reliab., vol. 55, no. 9-10, pp. 1708-1713, Aug. 2015. 